\title{
Characterization of $\mathrm{NiSO}_{4}$ Supported on $\mathrm{Fe}_{2} \mathrm{O}_{3}$ and Catalytic Properties for Ethylene Dimerization
}

\author{
Young Il Pae ${ }^{*}$ and Jong Rack Sohn \\ Department of Applied Chemistry, Engineering College, Kymgpook National Lniversity, Daegu 702-701, Korea \\ ${ }^{*}$ E-mail: jrsohnakm.ac.kr \\ ${ }^{\dagger}$ Department of Chemistry, Linversity of Llsan, Ulsan 680-746, Korea \\ Recerved Mav 22, 2007
}

\begin{abstract}
The $\mathrm{NiSO}_{4}$ supported on $\mathrm{Fe}_{2} \mathrm{O}_{3}$ catalysts were prepared by the impregnation method. No diffraction line of nickel sulfate was observed up to $30 \mathrm{wt} \%$. indicating good dispersion of nickel sulfate on the surface of $\mathrm{Fe}_{2} \mathrm{O}_{3}$. The addition of nickel sulfate to $\mathrm{Fe}_{2} \mathrm{O}_{3}$ shifted the phase transition of $\mathrm{Fe}_{2} \mathrm{O}_{3}$ (from amorphous to hematite) to higher temperatures because of the interaction between nickel sulfate and $\mathrm{Fe}_{2} \mathrm{O}_{3} .20-\mathrm{NiSO}_{4} / \mathrm{Fe}_{2} \mathrm{O}_{3}$ containing $20 \mathrm{wt} \%$ of $\mathrm{NiSO}_{+}$and calcined at $500^{\circ} \mathrm{C}$ exhibited a maximum catalytic activity for ethylene dimerization. The initial product of ethylene dimerization was found to be l-butene and the initially produced l-butene was also isomerized to 2-butene during the reaction. The catalytic activities were correlated with the acidity of catalysts measured by the ammonia chemisorption method
\end{abstract}

Key Words : $\mathrm{NiSO}_{4} / \mathrm{Fe}_{2} \mathrm{O}_{3}$ catalyst. Phase transition of $\mathrm{Fe}_{2} \mathrm{O}_{3}$, Acidic properties. Ethylene dimerization

\section{Introduction}

Heterogeneous catalysts for the dimerization and oligomerization of olefins. consisting mainly of nickel compounds supported on oxides. have been known for many years. The dimerization of alkenes is an important method for the production of higher olefins which find extensive application as industrial intermediate. A considerable number of papers have dealt with the problem of nickel-containing catalysts for ethylene dimerization. ${ }^{1-11}$ One of the remarkable features of this cataly'st system is its activity in relation to a series of $n$-olefins. In contrast to usual acid-type catalysts. nickel oxide on silica or silica-alumina shows a higher activity for a lower olefin dimerization. particularly for ethylene. ${ }^{1-6.12}$ It has been suggested that the active site for dimerization is formed by an interaction of a low-valent nickel ion with an acid site. ${ }^{9.13}$ It has been reported that the dimerization activities of such catalysts are related to the acidic properties of surface and low valent nickel ions. In fact. nickel oxide. which is active for $\mathrm{C}_{2} \mathrm{H}_{4}-\mathrm{C}_{3} \mathrm{D}_{4}$ equilibration. acquires an activity for ethylene dimerization upon addition of nickel sulfate. which is known to be an acid ${ }^{14} \mathrm{~A}$ transition metal can also be supported on zeolite in the state of a cation or a finely dispersed metal. Transition metal ions like $\mathrm{Ni}^{+}$or $\mathrm{Pd}^{+}$can be active sites in catalytic reactions such as ethylene and propylene dimerization as well as acetylene crelomerization. ${ }^{15-17}$

Many metal sulfates generate fairly large amounts of acid sites of moderate or strong strength on their surfaces when they are calcined at $400-700^{\circ} \mathrm{C} \mathrm{C}^{18.15}$ The acidic property' of metal sulfate often gives high selectivity for diversified reactions such as hydration. polymerization. alkylation. cracking and isomerization. However structural and physicochemical properties of supported metal sulfates are considered to be in different states compared with bulk metal sulfates because of their interaction with supports ${ }^{9.10 .2(1)}$ In the case of sulfate-promoted $\mathrm{Fe}_{2} \mathrm{O}_{3}$. the gas-phase skeletal isomerization of n-butane to isobutene took place even at 25 ${ }^{8} \mathrm{C}{ }^{21}$ From this fact. $\mathrm{Fe}_{2} \mathrm{O}_{3} / \mathrm{SO}_{4}{ }^{2-}$ was regarded as a superacid. This catalyst also showed high catalytic activities for the polymerization of alkyl vinyl ether. ${ }^{22}$ the double bond isomerization isomerization of 1-butene..$^{33}$ the ring-opening isomerization of cyclopropane. ${ }^{3.24}$ the dehydration of 2butanol. ${ }^{23.24}$ and the liquefaction of coal. ${ }^{25}$ Sulfated zirconia incorporating $\mathrm{Fe}$ and $\mathrm{Mn}$ has been shown to be highly active for butane isomerization. catalyzing the reaction even at room temperature ${ }^{26.27}$ Coelho et $a$ l. have discovered that the addition of $\mathrm{Ni}$ to sulfated zirconia causes an activity enhancement comparable to that caused the addition of $\mathrm{Fe}$ and Mn. ${ }^{28}$

So far. however. supported nickel sulfate catalysts have been used mainly on alumina. zirconia. and titania-zirconia. ${ }^{1.9 .29 .3(1)} \mathrm{NiSO}_{4}$ catalyst supported on $\mathrm{Fe}_{2} \mathrm{O}_{3}$ for ethylene dimerization have not been reported up to now. Therefore, in this paper. we tried to prepare new catalyst systems by supporting $\mathrm{NiSO}_{4}$ on $\mathrm{Fe}_{2} \mathrm{O}_{3}$. Characterization of $\mathrm{NiSO}_{4} /$ $\mathrm{Fe}_{2} \mathrm{O}_{3}$ and catalytic activity for ethylene dimerization are reported.

\section{Experimental Section}

Catalyst preparation. The catalysts was prepared as follows. The precipitate of $\mathrm{Fe}(\mathrm{OH})_{3}$ was obtained by adding aqueous ammonia slowly into an aqueous solution of iron nitrate at room temperature with stirring until the $\mathrm{pH}$ of the mother liquor reached about 8 . The precipitate. thus. obtained was washed thoroughly with distilled water and was dried at $100{ }^{\circ} \mathrm{C}$. The precipitate powdered below 100 mesh. Catalysts containing various nickel sulfate contents were prepared by the impregnation of $\mathrm{Fe}(\mathrm{OH})_{2}$ powder with 
an aqueous solution of $\mathrm{NiSO}_{4}$. followed by calcining at different temperatures for $1.5 \mathrm{~h}$ in air. This series of catalysts is denoted by the weight percentage of nickel sulfate. For example, $20-\mathrm{NiSO}_{4} / \mathrm{Fe}_{2} \mathrm{O}_{3}$ indicates the catalyst containing $20 \mathrm{wt} \%$ of $\mathrm{NiSO}_{4}$.

Procedure. FIIR spectra were obtained in a heatable gas cell at room temperature using a Mattson Model GL6030E spectrophotometer. The self-supporting catalyst wafers contained about $10 \mathrm{mg} \mathrm{cm}^{2}$. Prior to obtaining the spectra, we heated each sample under vacuum at $25-500^{\circ} \mathrm{C}$ for $1 \mathrm{~h}$. Catalysts were checked in order to determine the structure of the prepared catalysts by means of a P'hilips X'pert-APD Xray diffractometer, employing $\mathrm{Ni}$-filtered $\mathrm{Cu} \mathrm{K}$ \& radiation. DSC measurements were performed by a PL-STA model $1500 \mathrm{H}$ apparatus in air; the heating rate was $5^{\circ} \mathrm{C}$ per min. For each experiment $10-15 \mathrm{mg}$ of sample was used.

The specific surface area was determined by applying the BE'T method to the adsorption of $\mathrm{N}_{2}$ at $-196^{\circ} \mathrm{C}$. Chemisorption of ammonia was also employed as a measure of the acidity of catalysts. The amount of chemisorption was determined based on the irreversible adsorption of ammonia. ${ }^{31.32}$

The catalytic activity for ethylene dimerization was determined at $20^{\circ} \mathrm{C}$ using a conventional static system following the pressure change from an initial pressure of 290 Torr. A fresh catalyst sample of $0.2 \mathrm{~g}$ was used for every run and the catalytic activity was calculated as the number of moles of ethylene. Reaction products were analyzed by gas chromatography with a VZ-7 column at room temperature.

\section{Results and Discussion}

Infrared spectra. The infrared spectra of $20-\mathrm{NiSO}_{4} / \mathrm{Fe}_{2} \mathrm{O}_{3}$ $\left(\mathrm{KBr}\right.$ disc) calcined at different temperatures $\left(300-800{ }^{\circ} \mathrm{C}\right)$ are given in Figure $1.20-\mathrm{NiSO}_{4} / \mathrm{Fe}_{2} \mathrm{O}_{3}$ calcined up to $700^{\circ} \mathrm{C}$ showed infrared absorption bands at 1201, 1133, 1098 and $987 \mathrm{~cm}$ '. which are assigned to bidentate sulfate ions coordinated to the metal, such as $\mathrm{Fe}^{3+}$ or $\mathrm{Ni}^{2-31.32}$ For 20 $\mathrm{NiSO}_{4} / \mathrm{Fe}_{2} \mathrm{O}_{3}$ calcined at $700{ }^{\circ} \mathrm{C}$. the band intensities of sulfate ion decreased because of the partial decomposition of sulfate ion. However, for the sample calcined at $800^{\circ} \mathrm{C}$, infrared bands by the sulfate ion disappeared completely due to the decomposition of sulfate ion.

In general, for the metal oxides modified with sulfate ions followed by evacuation above $400^{\circ} \mathrm{C}$, a strong band ${ }^{3,3,4}$ assigned to $\mathrm{S}=\mathrm{O}$ stretching frequency is observed at 1390 $1360 \mathrm{~cm}^{-1}$. In a separate experiment, the infrared spectrum of self-supported $20-\mathrm{NiSO}_{4} / \mathrm{Fe}_{2} \mathrm{O}_{3}$ after evacuation at $500^{\circ} \mathrm{C}$ for $\mathrm{I} \mathrm{h}$ was examined. As shown in Figure $\mathrm{I}$, there is an intense band at $1376 \mathrm{~cm}^{-1}$, accompanied by four broad but split bands at $1182,1133,1028$ and $970 \mathrm{~cm}^{-1}$. indicating the presence of different adsorbed species depending on the treatment conditions of the sulfated sample. ${ }^{\text {is }}$

Crystalline structures of catalysts. The crystalline structures of $\mathrm{Fe}_{2} \mathrm{O}_{3}$ calcined in air at different temperatures for $1.5 \mathrm{~h}$ were checked by X-ray diffraction. As shown in Figure 2, $\mathrm{re}_{2} \mathrm{O}_{3}$ was amorphous to $\mathrm{X}$-ray diffraction at 25 ${ }^{\circ} \mathrm{C}$. However, from $300^{\circ} \mathrm{C}$ the phase transition of $\mathrm{He}_{2} \mathrm{O}_{3}$

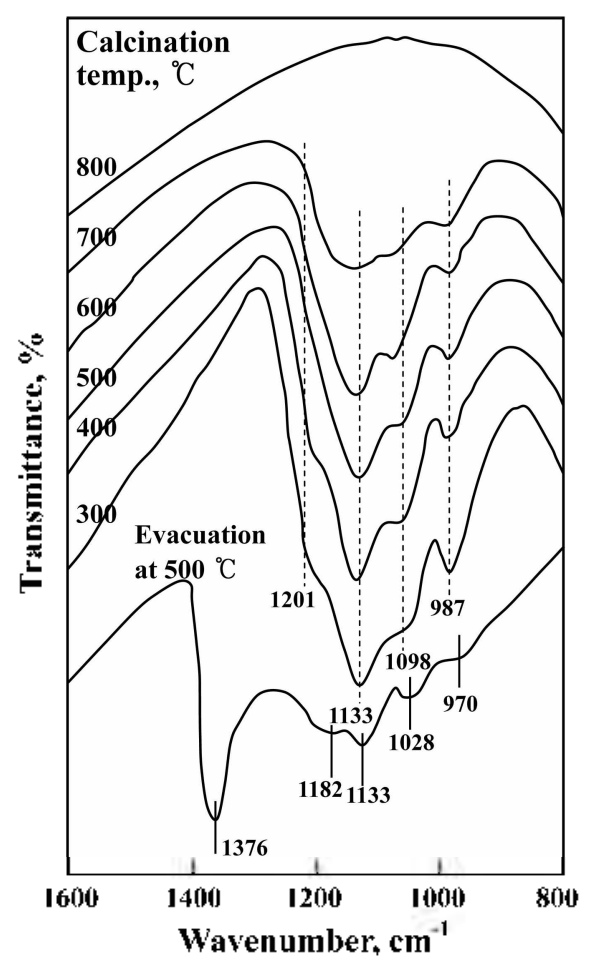

Figure 1. Infrared spectra of $20-\mathrm{NiSO}_{4} / \mathrm{Fe}_{2} \mathrm{O}_{5}$ calcined at different temperatures for $1.5 \mathrm{~h}$.

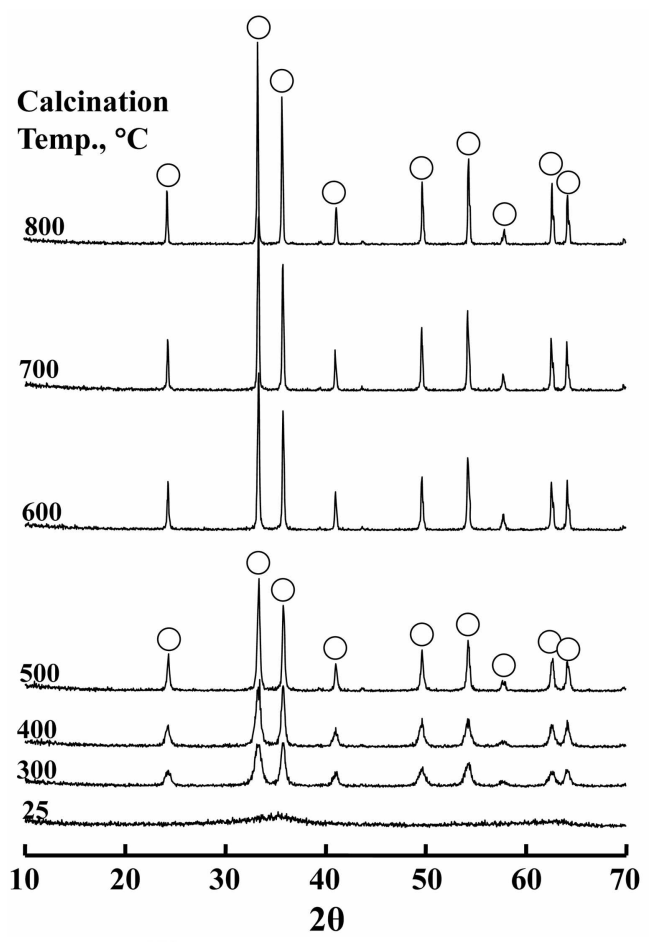

Figure 2. X-ray diffraction patterns of $\mathrm{Fe}_{2} \mathrm{O}_{\text {s }}$ calcined at different temperatures for $1.5 \mathrm{~h}:(\%)$, hematite phase of $\mathrm{Fe}_{2} \mathrm{O}_{3}$.

from amorphous to hematite occurred, showing that the intensity of hematite increased with the calcination temperature. In the case of supported nickel sulfate catalysts, the crystalline structures of the samples were different from that of the $\mathrm{He}_{2} \mathrm{O}_{3}$, support. The $20-\mathrm{NiSO}_{4} / \mathrm{Fe}_{2} \mathrm{O}_{3}$ materials calcin- 


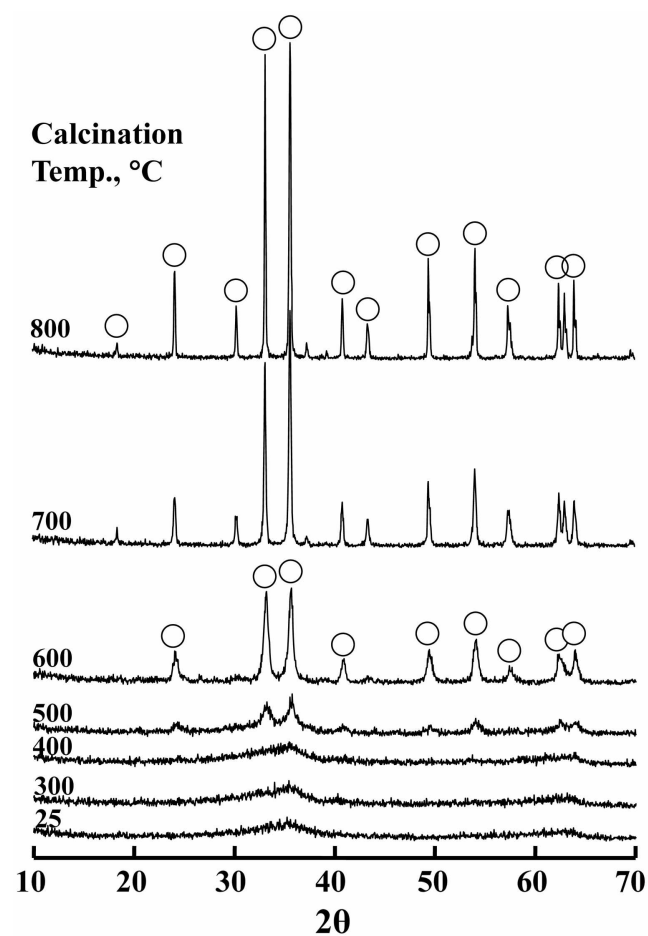

Figure 3. X-ray diffiaction pattems of $20-\mathrm{NiSO}_{4} / \mathrm{Fe}_{2} \mathrm{O}_{3}$ calcined at dillerent lemperatures for $1.5 \mathrm{~h}:(\therefore)$. hematite phase of $\mathrm{Fe}_{2} \mathrm{O}_{\mathrm{i}}$.

ed at different temperatures, as shown in Figure 3, are amorphous up to $400{ }^{\circ} \mathrm{C}$. In other words, the transition temperature from amorphous to hematite phase was higher by $200{ }^{\circ} \mathrm{C}$ than that of pure $\mathrm{Fe}_{2} \mathrm{O}_{3}{ }^{36}$ These results are similar to those of supported $\angle \mathrm{rO}_{2}$ catalysts, where the transition temperature from amorphous to tetragonal $\mathrm{ZrO}_{2}$ phase was higher by $200{ }^{\circ} \mathrm{C}$ than that of pure $7 . \mathrm{rO}_{2},{ }^{76} \mathrm{X}$-ray diffraction data indicated only the hematite phase of $\mathrm{Fe}_{2} \mathrm{O}_{3}$ at $500-800$ ${ }^{\circ} \mathrm{C}$, without detection of orthorhombic $\mathrm{NiSO}_{4}$ phase. It is assumed that the interaction between $\mathrm{NiSO}_{4}$ and $\mathrm{Fe}_{2} \mathrm{O}_{3}$ hinders the phase transition of $\mathrm{Fe}_{2} \mathrm{O}_{3}$ from amorphous to hematite. ${ }^{37}$ In this case, the amount of hematite also increased with the calcination temperature.

The XRD patterns of $\mathrm{NiSO}_{4} / \mathrm{Fe}_{2} \mathrm{O}_{3}$ containing different nickel sulfate contents and calcined at $500^{\circ} \mathrm{C}$ for $\mathrm{L} .5 \mathrm{~h}$ are shown in Figure 4. XRD data indicated only hematite phase of $\mathrm{Fe}_{2} \mathrm{O}_{3}$ at the region of $3-30 \mathrm{wt} \%$ of nickel sulfate, indicating good dispersion of $\mathrm{NiSO}_{4}$ on the surface of $\mathrm{Fe}_{2} \mathrm{O}_{3}$. However, the higher the content of $\mathrm{NiSO}_{4}$, the lower is the amount of hematite $\mathrm{Fe}_{2} \mathrm{O}_{3}$ phase, because the interaction between nickel sulfate and $\mathrm{He}_{2} \mathrm{O}_{3}$ hinders the phase transition of $\mathrm{He}_{2} \mathrm{O}_{3}$ from amorphous to hematite in proportion to the nickel sulfate content. ${ }^{3 \text { ? }}$

Thermal analysis. The $\mathrm{X}$-ray diffraction patterns in Figures 2-4 clearly show that the structure of $\mathrm{NiSO}_{4} / \mathrm{Fe}_{2} \mathrm{O}_{3}$ is different depending on the calcined temperature. To examine the thermal properties of precursors of $\mathrm{NiSO}_{4} / \mathrm{Fe}_{2} \mathrm{O}_{3}$ samples more clearly, we completed their thermal analysis; the results are illustrated in Figure 5 . For pure $\mathrm{Fe}_{2} \mathrm{O}_{3}$, the $\mathrm{DSC}$ curve shows a broad endothermic peak below $200^{\circ} \mathrm{C}$ due to water elimination, and an exothermic peak at $351^{\circ} \mathrm{C}$ due to

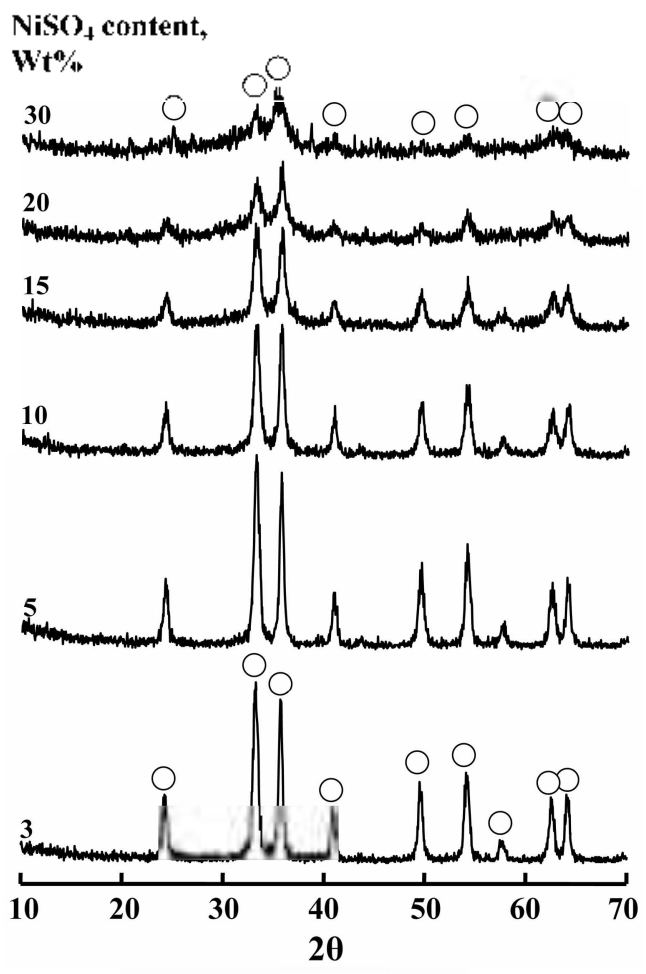

Figure 4. $\mathrm{X}$-ray diffraction paltems of $\mathrm{NiSO} / \mathrm{l} \mathrm{e}_{2} \mathrm{O}_{3}$ contiaining different $\mathrm{ViSO})_{+}$contents and calcined at $500{ }^{\circ} \mathrm{C}$ for $1.5 \mathrm{~h}$ ( (1). hematite phase of $\mathrm{Fe}_{2} \mathrm{O}_{1}$.

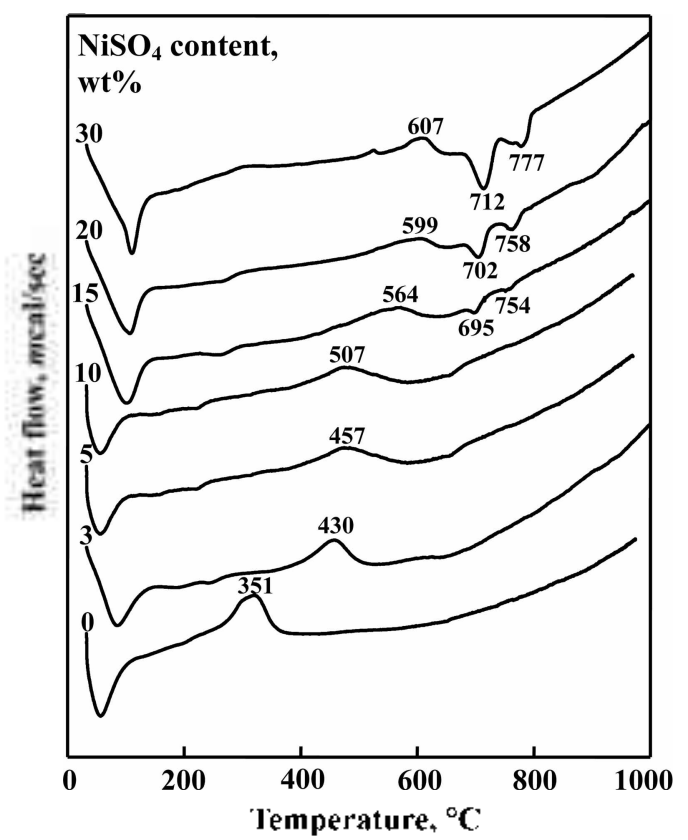

Figure 5. DSC curves of $\mathrm{NiSO}_{4} / \mathrm{FC}_{2} \mathrm{O}_{3}$ precursors containing different $\mathrm{.iSO}_{4}$ contents.

the $\mathrm{He}_{2} \mathrm{O}_{3}$ crystallization from amorphous to hematite phase ${ }^{\text {I2 }}$ However, it is of interest to see the influence of $\mathrm{NiSO}_{4}$ on the crystallization of $\mathrm{Fe}_{2} \mathrm{O}_{3}$ from amorphous to hematite phase. As Figure 5 shows, the exothermic peak due to the crystallization appears at $351{ }^{\circ} \mathrm{C}$ for pure $\mathrm{Fe}_{2} \mathrm{O}_{3}$, while for $\mathrm{NiSO}_{4} / \mathrm{Fe}_{2} \mathrm{O}_{3}$ samples it is shifted to higher temperatures 
due to the interaction between $\mathrm{NiSO}_{4}$ and $\mathrm{Fe}_{2} \mathrm{O}_{3}$. The shift increases with increasing $\mathrm{NiSO}_{4}$ content. Consequently, the exothermic peaks appear at $430^{\circ} \mathrm{C}$ for $3-\mathrm{NiSO}_{4} / \mathrm{Fe}_{2} \mathrm{O}_{3}, 457$ ${ }^{\circ} \mathrm{C}$ for $5-\mathrm{NiSO}_{4} / \mathrm{Fe}_{2} \mathrm{O}_{3}, 507{ }^{\circ} \mathrm{C}$ for $10-\mathrm{NiSO}_{4} / \mathrm{Fe}_{2} \mathrm{O}_{3}, 564{ }^{\circ} \mathrm{C}$ for $15-\mathrm{NiSO}_{4} / \mathrm{Fe}_{2} \mathrm{O}_{3}, 599^{\circ} \mathrm{C}$ for $20-\mathrm{NiSO}_{4} / \mathrm{Fe}_{2} \mathrm{O}_{3}$, and $607^{\circ} \mathrm{C}$ for $30-\mathrm{NiSO}_{4} / \mathrm{Fe}_{2} \mathrm{O}_{3}$.

The endothermic peaks for $\mathrm{N}_{1} \mathrm{SO}_{4} / \mathrm{Fe}_{2} \mathrm{O}_{3}$ samples containing $\mathrm{NiSO}_{4}$ content above $10 \mathrm{wt} \%$ in the region of 700-777 ${ }^{\circ} \mathrm{C}$ are due to the evolution of $\mathrm{SO}_{3}$ decomposed from sulfate species bonded to the surface of $\mathrm{Fe}_{2} \mathrm{O}_{3}$. However, as shown in Figure 5, two endothermic peaks for some samples due to the evolution of $\mathrm{SO}_{\text {s }}$ indicate that there are two different sulfate species on the surface of catalyst. For pure $\mathrm{NiSO}_{4}$. $6 \mathrm{H}_{2} \mathrm{O}$, the DSC curve shows three endothermic peaks below $400^{\circ} \mathrm{C}$ due to water elimination, indicating that the dehydration of $\mathrm{NiSO}_{4} \cdot 6 \mathrm{H}_{2} \mathrm{O}$ occurs in three steps. The endothermic peak around $837^{\circ} \mathrm{C}$ is due to the evolution of $\mathrm{SO}$; decomposed from nickel sulfate. ${ }^{.77 .38}$ Decomposition of nickel sulfate is known to begin at $700^{\circ} \mathrm{C} .{ }^{36}$

Specific surface area and acidity. The specific surface areas of samples containing different $\mathrm{NiSO}_{4}$ contents and calcined at $500{ }^{\circ} \mathrm{C}$ for $1.5 \mathrm{~h}$ are listed in Table 1 . The presence of nickel sulfate influences the surface area in comparison with that of the pure $\mathrm{Fe}_{2} \mathrm{O}_{3}$. Specific surface areas of $\mathrm{NiSO}_{4} / \mathrm{Fe}_{2} \mathrm{O}_{3}$ samples are larger than that of $\mathrm{Fe}_{2} \mathrm{O}_{3}$ calcined at the same temperature, showing that surface area increases gradually with increasing nickel sulfate loading up to $20 \mathrm{wt} \%$. It seems likely that the interactions between nickel sulfate and $\mathrm{Fe}_{2} \mathrm{O}_{3}$ prevent catalysts from crystallizing. ${ }^{10}$ The decrease of surface area for $\mathrm{NiSO}_{4} / \mathrm{Fe}_{2} \mathrm{O}_{3}$ samples containing $\mathrm{NiSO}_{4}$ above $20 \mathrm{wt} \%$ is due to the blocking of $\mathrm{Fe}_{2} \mathrm{O}_{3}$ pores by the increased $\mathrm{NiSO}_{4}$ loading. 'The acidity of catalysts calcined at $500^{\circ} \mathrm{C}$, as determined by the amount of $\mathrm{NH}_{3}$ irreversibly adsorbed at $230^{\circ} \mathrm{C}^{31 . .32}$ is also listed in

Table I. Surface area and acidity of $\mathrm{NiSO} \mathrm{O}_{+} / \mathrm{He}_{2} \mathrm{O}_{3}$ catalysts containing dilferent $\mathrm{NiSO}_{4}$ contents and calcined at $500^{\circ} \mathrm{C}$ lor I.5 h

\begin{tabular}{ccc}
\hline $\mathrm{NiSO}_{+}$content $(\mathrm{H} \%)$ & Surface arca $\left(\mathrm{m}^{2} / \mathrm{g}\right)$ & Acidity $(\mu \mathrm{mol} \mathrm{g})$ \\
\hline 0 & 10 & 21 \\
3 & 20 & 121 \\
5 & 44 & 138 \\
10 & 51 & 153 \\
15 & 63 & 240 \\
20 & 75 & 304 \\
30 & 56 & 278 \\
100 & 30 & 79 \\
\hline
\end{tabular}

Table 2. Surface area and acidity of $20-\mathrm{N}_{1} \mathrm{SO}_{4} / \mathrm{Fe}_{2} \mathrm{O}$; catalysts calcined at different temseratures for $1.5 \mathrm{~h}$

\begin{tabular}{ccc}
\hline Temperature $\left({ }^{\circ} \mathrm{C}\right)$ & Surface area $\left(\mathrm{m}^{2} / \mathrm{g}\right)$ & Acidity $(\mu \mathrm{mol} \mathrm{g})$ \\
\hline 300 & 153 & 338 \\
400 & 136 & 312 \\
500 & 75 & 304 \\
600 & 32 & 85 \\
700 & 24 & 30 \\
800 & 14 & 10 \\
\hline
\end{tabular}

Table 1. The variation of acidity runs parallel to the change of surface area. The acidity increases with increasing nickel sulfate content up to $20 \mathrm{wt} \%$ of $\mathrm{NiSO}_{4}$. The acidity is correlated with the catalytic activity for the ethylene dimerization discussed below. The surface area and acidity of $20-\mathrm{NiSO}_{4} / \mathrm{Fe}_{2} \mathrm{O}_{3}$ as a function of calcination temperature are listed in lable 2 . Both surface area and acidity decreased with the calcination temperature. Also, in this case, the variation of acidity runs parallel to the change of surface area. Especially, the remarkable decrease of surface area and acidity after $600{ }^{\circ} \mathrm{C}$ of calcination temperature is due to the decomposition of sulfate species on the surface of 20 $\mathrm{NiSO}_{4} / \mathrm{Fe}_{2} \mathrm{O}_{3}$, as shown in Figure 1.

Infrared spectroscopic studies of ammonia adsorbed on solid surfaces have made it possible to distinguish between Brönsted and Lewis acid sites. ${ }^{.8 .11 .42}$ Figure 6 shows the infrared spectra of ammonia adsorbed on $20-\mathrm{NiSO}_{4} / \mathrm{Fe}_{2} \mathrm{O}_{3}$ samples evacuated at $500{ }^{\circ} \mathrm{C}$ for $1 \mathrm{~h}$, For $20-\mathrm{NiSO}_{4} / \mathrm{Fe}_{2} \mathrm{O}_{3}$ the band at $1432 \mathrm{~cm}^{\prime}$ is the characteristic peak of ammonium ion, which is formed on the Bronsted acid sites and the absorption peak at $1612 \mathrm{~cm}^{1}$ is contributed by ammonia coordinately bonded to Lewis acid sites, ${ }^{38.41 .12}$ indicating the presence of both Brônsted and Lewis acid sites on the surface of $20-\mathrm{NiSO}_{4} / \mathrm{Fe}_{2} \mathrm{O}_{3}$ samples. Other samples having different nickel sulfate contents also showed the presence of both Lewis and Brônsted acids. As Figure 6(a) shows, the intense band at $1376 \mathrm{~cm}^{1}$ after evacuation at $500^{\circ} \mathrm{C}$ is assigned to the asymmetric stretching vibration of $\mathrm{S}=\mathrm{O}$ bonds having a high double bond nature. ${ }^{34.38}$ However, the drastic shift of the infrared band from $1376 \mathrm{~cm}^{1}$ to a lower

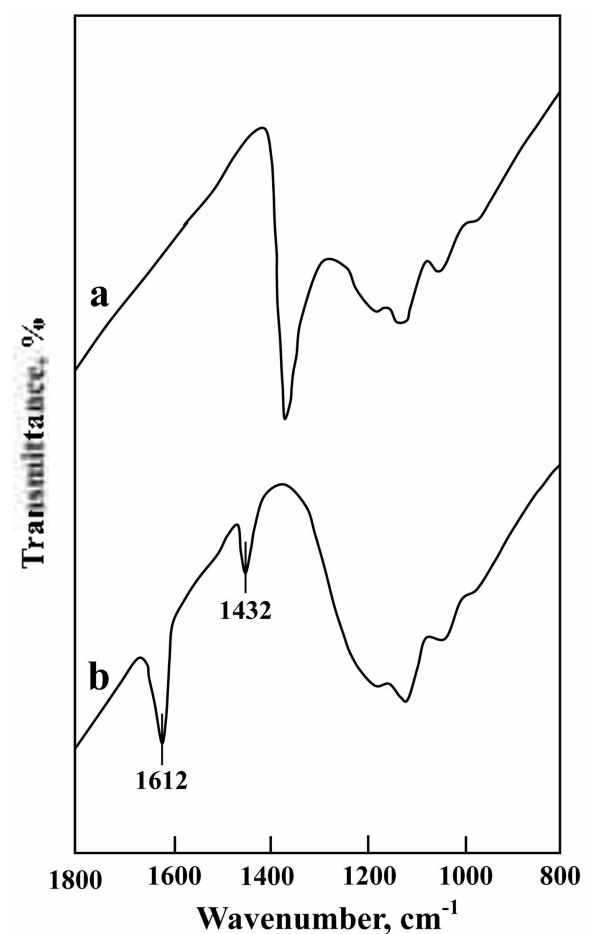

Figure 6. Infrared spectra of $\mathrm{NH}_{3}$ adsorbed on 20- $\mathrm{NiSO}_{4 /} \mathrm{FL}_{2} \mathrm{O}_{3}:$ (a) background of $20-\mathrm{NiSO}_{4} / \mathrm{Fe}_{2} \mathrm{O}_{\text {s }}$ after evacuation at $500^{\circ} \mathrm{C}$ for $\mathrm{I} \mathrm{h}$. (b) $\mathrm{NH}_{3}$ adsorthed on (a). where gas was evacuated at $230^{\circ} \mathrm{C}$ for $\mathrm{ll}$. 


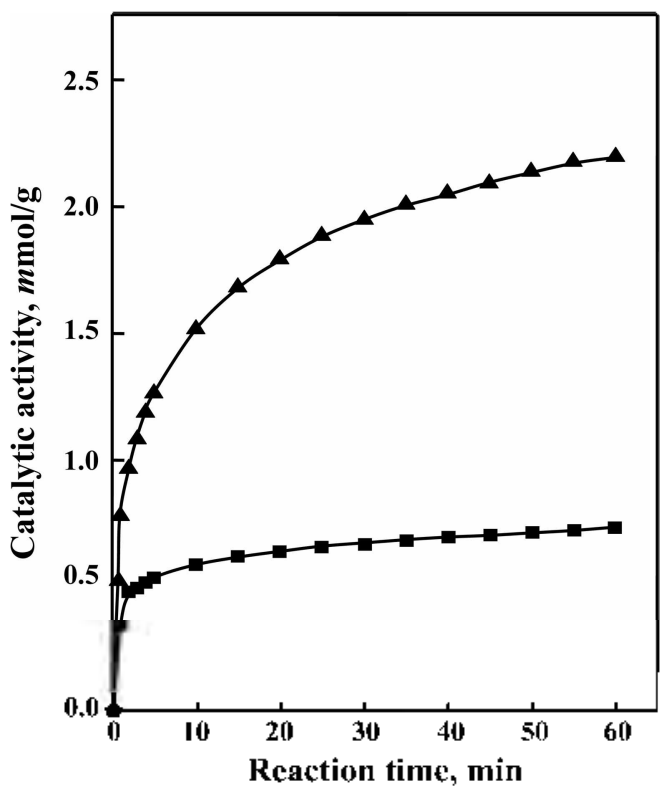

Figure 7. Time-course of ethylene dimerization over catalysts

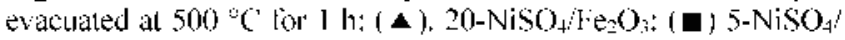
$\mathrm{l} \mathrm{wO}_{3}$.

wavenumber (not shown due to the overlaps of skeletal vibration bands of $\mathrm{Fe}_{2} \mathrm{O}_{3}$ ) after ammonia adsorption (Figure 6 (b)) indicates a strong interaction between an adsorbed ammonia molecule and the surface complex. Namely, the surface sulfur compound in the highly acidic catalysts has a strong tendency to reduce the bond order of $\mathrm{S}=\mathrm{O}$ from a highly covalent double-bond character to a lesser doublebond character when a basic ammonia molecule is adsorbed on the catalysts. ${ }^{3.138}$

Catalytic activities for ethylene dimerization. $\mathrm{NiSO}_{4}$ $\mathrm{Fe}_{2} \mathrm{O}_{3}$ catalysts were tested for their effectiveness in ethylene dimerization. Over $5-\mathrm{NiSO}_{4} / \mathrm{FeO}$; and $20-\mathrm{NiSO}_{4} / \mathrm{Fe}_{2} \mathrm{O}_{3}$, ethylene was continuously consumed, as shown by the results presented in Figure 7. where catalysts were evacuated at $500{ }^{\circ} \mathrm{C}$ for $1 \mathrm{~h}$. Over two catalysts, ethylene was selectively dimerized to $n$-butenes. However, we detected a sinall amount of hexenes from the phase that had adsorbed on the catalyst surface. Therefore, the deactivation of catalyst occurred slowly due to the adsorption of oligomers. In the composition of $n$-butenes analyzed by gas chromatography, 1 -butene was found to predominate exclusively at the initial reaction time, as compared with cis-butene and transbutene. This is because the initial product of ethylene dimerization is 1-butene. ${ }^{4.9 .42}$ Therefore, the initially produced 1-butene is also isomerized to 2-butene during the reaction time. $\$ 8.4 .3$

The catalytic activities of $20-\mathrm{NiSO}_{4} / \mathrm{Fe}_{2} \mathrm{O}_{3}$, were tested as a function of calcination temperature: the results are shown in Figure 8 . The activities increased with the calcination temperature, reaching a maximum at $500{ }^{\circ} \mathrm{C}$. and then the activities decreased. 'Jhese results are very similar to those reported by other authors, ${ }^{4.45}$ where sulfated $\mathrm{He}_{2} \mathrm{O}_{3}$ catalyst calcined at $500^{\circ} \mathrm{C}$ exhibited a maximum catalytic activity. The decrease of catalytic activity after calcination above 500

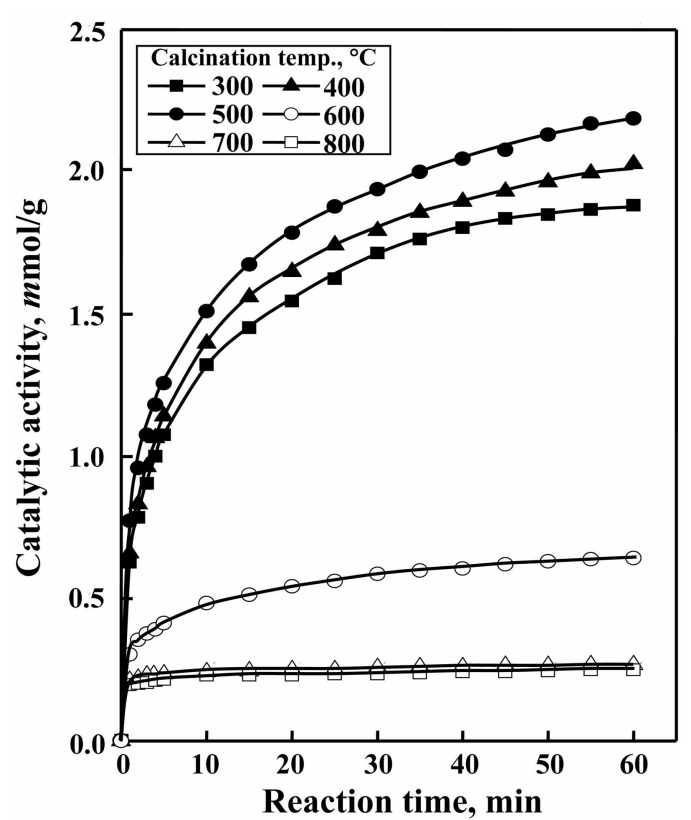

Figure 8. Catalytic activity of $20-\mathrm{NiSO}_{4} / \mathrm{I}_{2} \mathrm{O}_{3}$ for ethylente dimerization as as function of ealcination kemperature.

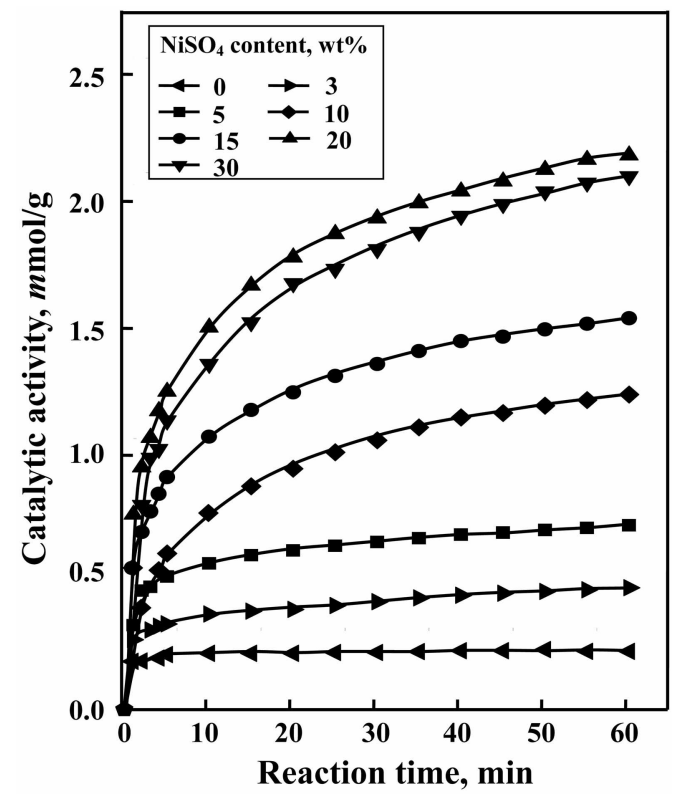

Figure 9. Catalytic activity of $\mathrm{NiSO} / \mathrm{Fe}_{2} \mathrm{O}_{\text {: }}$ for ethylene dimerization as a function of $\mathrm{NiSO}_{4}$ content.

"C can be probably attributed to the fact that the surface area and acidity above $500{ }^{\circ} \mathrm{C}$ decrease with the calcination temperature. As listed in lable 2, both surface area and acidity above $500^{\circ} \mathrm{C}$ decreased with the calcination temperature.

Catalytic activity as a function of $\mathrm{NiSO}_{4}$ content. The catalytic activity of $\mathrm{NiSO}_{4} / \mathrm{Fe}_{2} \mathrm{O}_{3}$ containing different $\mathrm{NiSO}_{4}$ contents was examined; the results are shown as a function of $\mathrm{NiSO}_{4}$ content in Figure 9. Catalysts were evacuated at $500{ }^{\circ} \mathrm{C}$ for $\mathrm{l} \mathrm{h}$ before each reaction. The catalytic activity gives a maximum at $20 \mathrm{wt} \%$ of $\mathrm{NiSO}_{4}$. This seems to be 


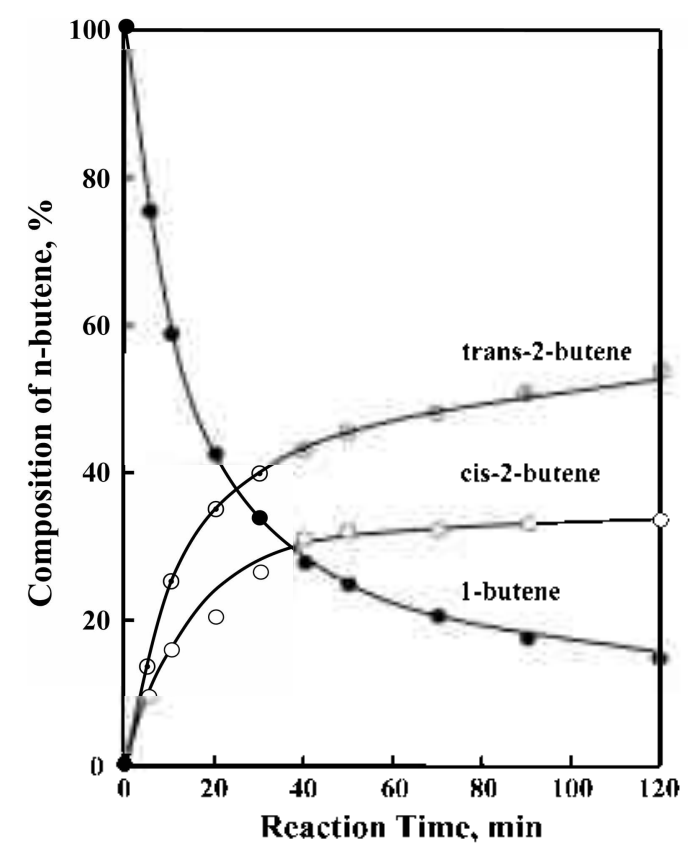

Figure 10. Variation of product composition in ethylene dimeriration on $20-\mathrm{NiSO}_{4} / \mathrm{l} \mathrm{e}_{2} \mathrm{O}_{3}$ with reaction lime.

correlated to the specific surface area and to the acidity of catalysts. The acidity of $\mathrm{NiSO}_{4} / \mathrm{\Gamma e}_{2} \mathrm{O}_{3}$ calcined at $500^{\circ} \mathrm{C}$ was determined by the amount of $\mathrm{NH}_{3}$ irreversibly adsorbed at $230^{\circ} \mathrm{C} .^{31.32}$ As listed in Table 1, the BIT surface area attained a maximum extent when the $\mathrm{NiSO}_{4}$ content in the catalyst was $20 \mathrm{wt} \%$ and then showed a gradual decrease with increasing $\mathrm{NiSO}_{4}$ content. In view of Table 1 and Figure 9 , the higher the acidity, the higher the catalytic activity. Good correlations have been found in many cases between the acidity and the catalytic activities of solid acids. For example, the rates of both the catalytic decomposition of cumene and the polymerization of propylene over $\mathrm{SiO}_{2}-$ $\mathrm{Al}_{2} \mathrm{O}_{3}$ catalysts were found to increase with increasing acid amount at strength $\mathrm{H}_{0} \leq+3.3 .{ }^{+0}$ The catalytic activity of nickel-containing catalysts in ethylene dimerization as well as in butene isomerization is closely correlated with the acidity of the catalyst. ${ }^{40,10,43}$

Variation of product composition in ethylene dimerization. It is necessary to confirm that the initial product of ethylene dimerization is 1-butene. The compositions are plotted against the reaction time in Figure 10 . In the composition of $n$-butenes analyzed by gas chromatography, 1-butene was found exclusively at the initial reaction time, and no cis- or trans-2-butanes were found. However, the amount of 1-butene decreases with the reaction time, while the amount of 2-butenes increases. Therefore, it is obvious that the initially produced 1-butene is also isomerized to 2butene during the reaction. ${ }^{4.9} \mathrm{NiSO}_{4} / \mathrm{He}_{2} \mathrm{O}_{3}$ was effective for ethylene dimerization, but $\mathrm{He}_{2} \mathrm{O}_{3}$ without $\mathrm{NiSO}_{4}$ and pure $\mathrm{NiSO}_{4}$ without $\mathrm{Fe}_{2} \mathrm{O}_{3}$ exhibited absolutely no catalytic activity.

Catalytic activity as a function of acidity. As mentioned above, the active site responsible for dimerization is suggested to consist of a low valent nickel ion and an acid,

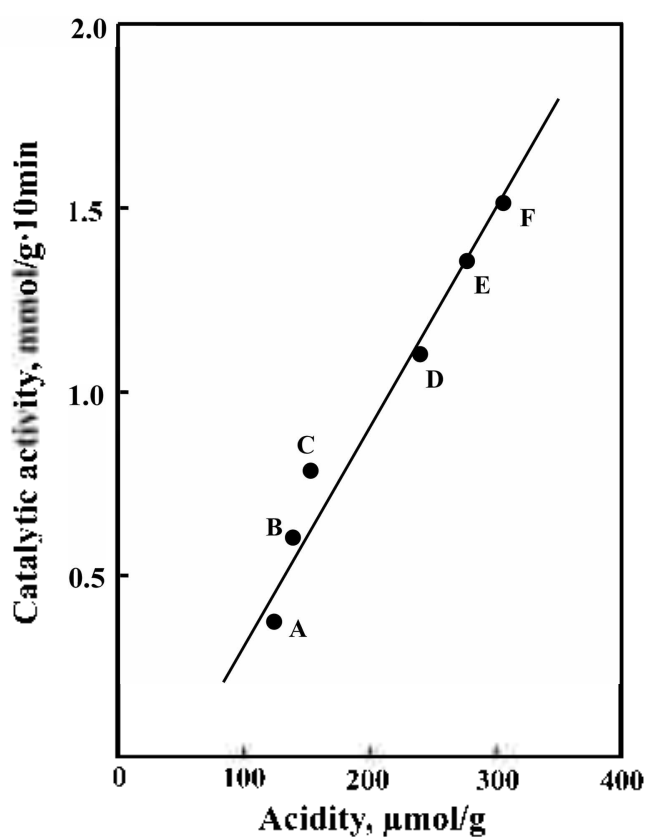

Figure 11. Cortelationship between catalytic activity and acidity: (A) 3-NiSO./1 $\mathrm{C}_{2} \mathrm{O}_{3}$ (B) $5-\mathrm{NiSO}_{1} / \mathrm{Fe}_{2} \mathrm{O}_{3 .}$ (C) $10-\mathrm{NiSO}_{1} / \mathrm{Fe}_{2} \mathrm{O}_{3 .}$ (D) 15- $\mathrm{NiSO}_{4} / \mathrm{Fe}_{2} \mathrm{O}_{3 .}$ (E) $30-\mathrm{NiSO}_{4} / \mathrm{Fc}_{2} \mathrm{O}_{3}$. and (F) $20-\mathrm{NiSO}_{4} / \mathrm{Fe}_{2} \mathrm{O}_{3}$.

as observed in the nickel-containing catalyst..$^{1.30 .38} \mathrm{~A}$ lowvalent nickel, $\mathrm{Ni}^{+}$, plays the role of an adsorption site for ethylene, while acidic sites are responsible for the formation of reaction intermediates such as ethyl cations. ${ }^{38}$ It is known that for ethylene dimerization the variations in catalytic activities are closely correlated to the acidity values of catalyst. ${ }^{30.17}$ The acidity values of several samples after evacuation at $400^{\circ} \mathrm{C}$ are listed in Table I together with their surface areas. In view of Table 1 , the catalytic activities substantially run parallel to the acidity values. The catalytic activities of $\mathrm{NiSO}_{4} / \mathrm{Fe}_{2} \mathrm{O}_{3}$ catalysts containing different $\mathrm{NiSO}_{4}$ contents were examined; the results are shown as a function of acidity in figure 11, where catalysts were evacuated at $500^{\circ} \mathrm{C}$ for $\mathrm{I} \mathrm{h}$ before reaction. It is confirmed that the catalytic activity gives a maximum at $20-\mathrm{NiSO}_{4} /$ $\mathrm{He}_{2} \mathrm{O}_{5}$ containing 20 wt $\%$ of $\mathrm{NiSO}_{4}$. This seems to be correlated to the specific surface area and to the acidity of the catalysts. The acidity of catalysts calcined at $500{ }^{\circ} \mathrm{C}$ was determined by the amount of $\mathrm{NH}_{3}$ irreversibly adsorbed at $230^{\circ} \mathrm{C} .4,4.69 .48$ As shown in Figure 11 , the higher the acidity, the higher the catalytic activity. In this way it is demonstrated that the catalytic activity of supported $\mathrm{NiSO}_{4}$ catalysts essentially runs parallel to the acidity. Good correlations have been found in many cases between the acidity and the catalytic activities of solid acids. It has been reported that the catalytic activity of nickel-containing catalysts in ethylene dimerization as well as in butene isomerization are closely correlated with the acidity of the catalysts. ${ }^{3.4,6.30}$

\section{Conclusions}

A series of catalysts, $\mathrm{NiSO}_{4} / \mathrm{Fe}_{2} \mathrm{O}_{3}$, was prepared by the 
impregnation method using an aqueous solution of nickel sulfate. The addition of nickel sulfate to $\mathrm{Fe}_{2} \mathrm{O}_{3}$ shifted the phase transition of $\mathrm{Fe}_{2} \mathrm{O}_{3}$ (from amorphous to hematite) to higher temperatures because of the interaction between nickel sulfate and $\mathrm{Fe}_{2} \mathrm{O}_{3}, 20-\mathrm{NiSO}_{4} / \mathrm{Fe}_{2} \mathrm{O}_{3}$ containing 20 wt $\%$ of $\mathrm{NiSO}_{4}$ and calcined at $500{ }^{\circ} \mathrm{C}$ exhibited a maximum catalytic activity for ethylene dimerization. $\mathrm{NiSO}_{4} / \mathrm{Fe}_{2} \mathrm{O}_{3}$ catalysts were very effective for ethylene dimerization even at room temperature. but $\mathrm{Fe}_{2} \mathrm{O}_{3}$ without $\mathrm{NiSO}_{4}$ did not exhibit any catalytic activity at all. The cataly tic activity was correlated with the acidity of catalysts measured by the anmionia chenisorption method.

Acknowledgements. This work was supported by 2006 Research Fund of University of Ulsan. We wish to thank Korea Basic Science Institute (Daegu Branch) for the use of their X-ray diffractometer.

\section{References}

1. Pae. Y. I.: Lee. S. H.: Sohn. J. R. Catal. Lett 2005.99. 241

2. Bernardi. F.: Bottoni. A.: Rossi. I. J. Am. Chem. Soc. 1998. I20. 7770 .

3. Solm I. R: Ozaki, A. J Catal 1979,59,303

4. Solm, J. R. Ozaki, A. J. Catal 1980, 61, 29.

5. Wendt. G; Fritsch. E; Schöllner. R.: Siegel. H. Z. Anorg. Allg. Chem. 1980 +67.51

6. Sohn. J. R.: Shin. D. C. J. Catat. 1996. I60. 314.

7. Berndt. G. F.: Thomson. S. J.: Webb. G. J. J. Chem. Soc. Faradoy Trans. 1983. 179.195

8. Herwijnen, T. V: Doesburg, H. V.: Jong, D. V. J. Catal. $1973,28$. 391

9. Solm J. R: Park W. C.: Kim. H. W. J. Catal 2002, 209.69.

10. Sohn. J. R.: Park. W. C. Bull Korean Chem. Soc. 2000. 21. 1063.

11. Urabe. K.: Koga. M.: Izumi. Y. J. Chem. Soc. Chem Commun. 1989.807.

12. Wendt. G.: Hentschel. D.: Finster. J: Schölner R. J. Chem. Soc. Faraday Trans. 1983, 179. 2013

13. Kimura, K. Ozaki A. J. Catal 1964, 3, 395.

14. Maruya. K.: Ozaki. A. Bull. Chent. Soc.Jpn. 1973. 46.351

15. Hartmann. M.: Pöppl. A.: Kevan. L. J. Phns. Chent 1996. I00. 9906.

16. Elev, I. V: Shelinov, B. N.: Kazansky, V. B. J. Catal. $1984,89$.
470

17. Choo. H.: Kevant. L. J. Phys. Chem. B 2001. 105. 6353.

18. Tanabe. K.: Misono. M.: Ono. Y.: Hattori. H. New Solid.Acids and Bases: Kodansha-Elsevier: Tokvo. 1989: p 185.

19. Arata. K: Hino, M: Yamagata. N. Bull Chem. Soc. Jph 1990.63. 244.

20. Soht1. J. R.: Kim. H. W.: Lim. I. S. J. Ind. Eng. Chem. 2006.12. I04.

21. Hino. M.: Arata. K. Chem. Lett. 1979. 1259

22. Hino. M.: Arata. K. Chem. Lett. 1980. 963

23. Tanabe, K.: Kayo. A.: Yamaguchi, T. d. Chem Soc. Chem Conmun. 1981.602.

24. Kayo. A.: Yamaguchi. T.: Tanabe. K. J. Catal 1983. 83. 99.

25. Tanabe. K.: Hattori. H.: Yamaguchi. T: Yokoyama. S.: Unematsu. J.: Sanada. Y. Fuel 1982.61. 389

26. Hsu. C. Y.: Heimbuch, C. R: Armes. C. T.: Gates, B. C. J. Chem Soc. Chem. Commun. 1992, 1645

27. Cheung, T. K. Gates, B. C. . Catal. 1997, 168. 522

28. Coelho. M. A.: Resasco. D. E.: Sikabwe. E. C.: White. R. L. Catal. Lett. 1995. 32.253

29. Sohn1. T. R.: Lee. S. H. Appl Catal. A: Gen. 2004. 266.89.

30. Sohn. J. R.: Lim. J. S. Bull. Korzan Chem. Soc. 2005. 26, 1029.

31. Sohn, J. R.: Lee. S. G.: Shin. D. C. Bull. Korean Chem. Soc. 2006. 27. 1623 .

32. Sohn1. J. R.: Kiml. J. G.: Kwonl. T. D.: Park. E. H. Langmir 2002. 18. 1666.

33. Saur. O.: Bernsitel. M. A. B.: Saad. M.: Lavalley. J. C.: Tripp. C P.; Morrow, B. A. J. Catal 1986. 99. 104.

34. Yamaguchi. T. Appl. Catal 1990, 61. 25.

35. Morrow, B. A.; McFarlane, R. A.; Lion, M.: Lavalley, J. C. $d$ Catal. 1987.107.232.

36. Soht1. T. R.: Park. W. C. Appl. Catal. A: Gen. 2002. 230. 11

37. Hua. W.: Xia. Y.: Yue. Y.: Gao. Z. J. Catal 2000. 196. 104.

38. Sohn, J. R.: Park. W. C. Appl. Catal A: Gen. 2003. 239. 269.

39. Siriwardane, R. V; Poston, J. A. Jr.: Fisher. E. P; Shen, M. S; Miltz. A. L. Appl. Suff. Sci. 1999. 152, 219.

40. Sohn1. T. R. J. Ind Eng. Chem. 2004. 10. 1.

41. Satsuma. A.: Hattori. A.: Mizutanii. K.: Furuta. A.: Miyamoto. A. Hattori. T.: Murakami. Y. J. Phws. Chent. 1988. 92.6052.

42. Sohn. J. R.: Lee. S. H. Appl. Catal. A: Gen. 2004, 266,89.

43. Sohn. J. R.: Lee. S. H. Appl. Catal. A: Gen. 2007, 321, 27

4. Arata, K. Ad. Catal 1990, 37. 165.

45. Yamaguch. T.: Jim. T.: Tanabe. K. J. Phs Chem. 1986. 90. 3148

46. Tanabe. K. Solid Acids and Bases: Kodansha. Tohyo. 1970) p 103.

47. Sohn1. T. R.: Lim1. J. S. Catal. Todan 2006. 111. 403

48. Sohn. J. R.: Han. J. S. J. Ind. Eng. Chem. 2005, 11,439 